\title{
原著 3
}

\section{痛風における心筋梗塞の関連性}

緒言

痛風は単純な関節病変ではなく，様々な疾患 を合併する全身的な疾患と認識されている。近 年，その合併症の中でも特に脳血管障害あるい は虚血性心疾患との関連性が注目されている。 痛風に虚血性心疾患が合併することは既に古く からよく知られているが1), 痛風患者には高血圧, 糖尿病, 高脂血症などのリスクファクターが併 存することが多く, 痛風あるいは高尿酸血症は 虚血性心疾患の独立したリスクファクターでは ないと考える研究者も少なくない2 2 4)。逆に, 血 清尿酸值と「心血管事故死」との関連を, 高血 圧, 糖尿病, 高脂血症, 年令などの因子で補正
陳 峙仰 ${ }^{1)}$ 鎌谷 直之 ${ }^{2)}$

したprospective cohort study から，血清尿酸值の 上昇は心血管事故死の独立したリスクファク夕 一であるとする報告も見られるなど5-9)，「心血 管事故」に対する血清尿酸值のリスクの問題は controversialである.

ところで，著者らは「心血管事故死」と「心 血管事故の発生」は同じではないと考えている. 心血管事故死に対する血清尿酸値のリスクを検 討する場合には，尿酸值を上昇させる可能性の ある長期の利尿薬やアスピリン製剤の服用によ るバイアスを考慮に入れる必要があるにもかか わらず，従来の研究では完全に行われていなか った。また，従来の報告のなかで「心血管事故」

表1 痛風,血清尿酸值と心血管事故の関連を検討した従来の研究

\begin{tabular}{|c|c|c|c|c|c|}
\hline 研究の名称 & 対象集団 & 研究因子 & 心血管事故の定義 & $\begin{array}{c}\text { 血清尿酸值の } \\
\text { 最高なクオータイル }\end{array}$ & $\begin{array}{l}\text { 心血管事故と } \\
\text { 関連性の有無 }\end{array}$ \\
\hline Framingham Study (10) & \begin{tabular}{|c} 
利尿薬の使用歴のない \\
正常人集団
\end{tabular} & 痛風の有無 & 虚血性心疾患の発生 & - & 男性にあり \\
\hline $\begin{array}{l}\text { NHANES I Study, } \\
1971-1987(11)\end{array}$ & 正常人集団 & 血清尿酸值 & $\begin{array}{c}\text { 虚血性心疾患の } \\
\text { 入院歴の有無 }\end{array}$ & $\geq 7 \mathrm{mg} / \mathrm{dL}$ & 女性にあり \\
\hline $\begin{array}{l}\text { Framingham } \\
\text { Heart Study (12) }\end{array}$ & 正常人集団 & 血清尿酸值 & 虚血性心疾患の発生 & $\geq 6.72 \mathrm{mg} / \mathrm{dL}$ & なし \\
\hline $\begin{array}{l}\text { Meharry-Hopkins } \\
\text { Study (13) }\end{array}$ & 若い男性医学生の集団 & 痛風の有無 & 虚血性心疾患の発生 & - & なし \\
\hline Worksite Study (14) & 高血圧患者集団 & 血清尿酸值 & $\begin{array}{c}\text { 虚血性心疾患,心不全, } \\
\text { 脳卒中などの発生 }\end{array}$ & $\geq 6.22 \mathrm{mg} / \mathrm{dL}$ & なし \\
\hline PIUMA Study (15) & 高血圧患者集団 & & $\begin{array}{c}\text { 虚血性心疾患,心不全, } \\
\text { 脳卒中,透析導入の必要のある } \\
\text { 腎不全,動脈閉塞などの発生 }\end{array}$ & $\geq 6.2 \mathrm{mg} / \mathrm{dL}$ & ややあり \\
\hline
\end{tabular}

受付：2004年 6 月 2 日，受理：2004年 9 月 10 日

1）台北市立和平医院痛風科

2 ）東京女子医科大学附属膠原病リウマチ痛風センター

Shih-Yang Chen

Naoyuki Kamatani 
と定義されているものには, 虚血性心疾患だけ ではなく，すべての心臓病，さらには脳卒中な ども含まれているものもあって，虚血性心疾患 を独立したリスクとして検討したものはわずか4 件であり（表 1 ），さらに痛風を独立したリスク として扱ったものはその内の 2 件にすぎなかっ た ${ }^{10,11)}$.このように, 現時点では血清尿酸值の上 昇や痛風が虚血性心疾患の独立したリスクであ るというエビデンスも確立されていないと思わ れる。このほか, 従来の研究で対象になってい るのは正常人や高血圧患者集団であり，血清尿 酸值の分類は表 1 に示したようにほとんど 7 $\mathrm{mg} / \mathrm{dL}$ 以下に設定されているが，このことも血 清尿酸值の虚血性心疾患に対するリスクが低く 評価される原因になるのではなからうか. 痛風 がいわゆる無症候性高尿酸血症と異なる点は, 痛風は高尿酸血症が持続して「尿酸塩沈着が進 行した状態」であり，無症候性高尿酸血症より も虚血性心疾患に対するリスクは高いことが予 測される，著者らが調べた範囲では，従来の報 告の中で痛風と虚血性心疾患の関連性を検討し たものは 2 件のみで10,13)，しかも両者の間に有意 な相関を認めたものは1988年のFramingham Study だけであった ${ }^{(0)}$. 血清尿酸值と痛風の臨床因子を 含めて虚血性心疾患との関連を検討した報告は 未だなされていないので, 今回著者らは, 心電 図からみた心筋梗塞と痛風の関連について検討 した。

\section{対象及び方法}

和平医院痛風データベース

台北市立和平医院痛風外来には, 台湾痛風の 臨床研究を目的として1983年以来の全ての痛風 患者についての初診時の臨床及び検査データが 蓄積されている.今回の研究の対象は,このデ ータベースにある28,660名の痛風患者のうち心電 図データのあった28,639名である。心筋梗塞の診 断は心電図上で病的Q波 $(>0.04 \mathrm{~s},>\mathrm{R}$ 波の高さ の25\%）があったものと定義した ${ }^{16)}$. 心電図の判 読は全て 1 人の心臓病専門医が担当した。心筋梗 塞の診断は, 臨床症状, 血清学的検査值, 心電図
などを総合して行われるべきであり，心電図のみ の診断では当然のことながら偽陽性例が混入する 可能性がある.しかし, 本研究が巨大なデータベ 一スに基づいた検討であることは，相関検出力の 低下をかなり補償できると考えている.

また，HDLやLDLなどのデー夕も入っていな いが，脂質代謝の異常はトリグリセライドや総 コレステロール值で表現されるので, 影響も少 ないと考えられる。

\section{研究のプロトコール}

対象を心筋梗塞の心電図所見の有無によって 2 群に分け, 既知の虚血性心疾患のリスクファ クターを補正し, 痛風の臨床因子と心筋梗塞に 対する関連をlogistic 回帰解析で検討した。補正 した既知の虚血性心疾患のリスクファクターは, 年令, 性別, 喫煙歴, 飲酒習慣, 利尿薬の使用 歴, 総コレステロール值, トリグリセライド值, 高血圧, 糖尿病, BMI值などである。まず, 全 症例について心筋梗塞に対する関連性を検討し, ついて男性痛風群, 女性痛風群, 50 才以上痛風 群 ( 250 才), 50才未満痛風群（<50才）に分け て検討した。

痛風の臨床因子では血清尿酸值, 痛風の罹病 期間 (初発痛風発作からの年数) および関節数, 痛風結節, 発作の頻度などのパラメターをまず 単変量解析で, ついて既知のリスクファクター を多変量解析で補正し，それぞれのパラメター の心筋梗塞に対する関連を検討した。血清尿酸 值（SUA） はSUA $\leq 7,7<\mathrm{SUA} \leq 8,8<\mathrm{SUA}$ $\leq 9,9<\mathrm{SUA} \leq 10,10<\mathrm{SUA} \leq 11, \quad \mathrm{SUA}>$ $11 \mathrm{mg} / \mathrm{dL}$ の 6 段階に分け, 痛風発作の頻度は 1 年に 1 回， $2 \sim 5$ 回， 6 回以上の 3 段階に区分 して検討した。

\section{結 果}

28,639名の痛風患者の内393名 $(1.4 \%)$ に, 心 電図上で心筋梗塞の所見があった．全症例の背 景因子 (表 2) のなかで, 飲酒習慣抢よび喫煙歴 が心筋梗塞のありと関連を示さなかったことは 一般的な認識と異なるが，重要な意味を有する 
表2 全痛風患者の痛風背景因子と心筋梗塞の相関

\begin{tabular}{|c|c|c|c|}
\hline & $\begin{array}{c}\text { 心筋梗塞あり }) \\
\quad(n=393)\end{array}$ & $\begin{array}{c}\text { 心筋梗塞なし } \\
(n=28246)\end{array}$ & $P$ 值 \\
\hline 初診時年令 (才) & $58.0 \pm 13.1$ & $51.0 \pm 14.4$ & $<0.0001$ \\
\hline 血清尿酸值 (mg / dL) & $10.2 \pm 1.7$ & $10.1 \pm 1.6$ & 0.0536 \\
\hline 罹病期間 (年) & $5.3 \pm 6.0$ & $4.7 \pm 5.1$ & 0.0003 \\
\hline 痛風結節 (\%) & 12.4 & 8.9 & 0.0002 \\
\hline 関節数 & $2.9 \pm 1.5$ & $2.5 \pm 1.4$ & $<0.0001$ \\
\hline 発作回数>6回 /年 (\%) & 55.5 & 48.0 & $<0.0001$ \\
\hline 女性痛風 (\%) & 15.1 & 7.6 & $<0.0001$ \\
\hline 飲酒習慣 (\%) & 19.9 & 23.6 & 0.0099 \\
\hline 喫煙歴 (\%) & 31.8 & 31.1 & 0.6497 \\
\hline 利尿薬の使用 (\%) & 2.7 & 2.1 & 0.1973 \\
\hline 高血圧 (\%) & 47.6 & 26.2 & $<0.0001$ \\
\hline 総コレステロール (mg/dL) & $213.2 \pm 44.8$ & $208.1 \pm 45.9$ & 0.0006 \\
\hline トリグリセライド(mg/dL) & $207.9 \pm 137.2$ & $187.4 \pm 126.4$ & $<0.0001$ \\
\hline 空腹時血糖值 $(\mathrm{mg} / \mathrm{dL}$ ) & $109.3 \pm 41.2$ & $101.9 \pm 26.7$ & $<0.0001$ \\
\hline BMI值 $\left(\mathrm{Kg} / \mathrm{m}^{2}\right)$ & $26.2 \pm 4.0$ & $25.8 \pm 3.9$ & 0.0015 \\
\hline
\end{tabular}

数值は平均值士SD またはパーセンテージ
喫煙量あるいは飲酒量に関して検討できなかっ たことに原因があると考えている。

全痛風群に打いて心筋梗塞は，既知のリスク ファクターを補正すると, 血清尿酸值, 関節数, 発作回数が有意な相関を示した（表 3 ). 発作の あった関節数と発作回数は既知のリスクファク ターおよび血清尿酸值を補正しても有意な相関 を示したが，他の痛風因子を全て加えて補正す ると，血清尿酸值だけが有意な相関を示した。

男性痛風群において心筋梗塞の関連因子は全 痛風群とほぼ同じであるが, 発作回数は既知の リスクファクターや血清尿酸值を補正すると有 意な相関が無くなった（表 3 ).

女性痛風群における心筋梗塞の関連因子では, 血清尿酸值, 痛風の罹病期間, 関節数, 痛風結 節は有意な相関を示さなかった。発作回数は既 知のリスクファクターを補正すると有意な相関 を示したが，血清尿酸值を補正すると，有意な 相関も無くなった（表 3 ).

\section{表3 全痛風,男性痛風および女性痛風患者における心筋梗塞の痛風関連因子}

\begin{tabular}{|c|c|c|c|c|c|}
\hline & & 補正前 & $\begin{array}{c}\text { 既知のリスクファクターを } \\
\text { 補正した後* }\end{array}$ & $\begin{array}{l}\text { 既知のリスクファクターと } \\
\text { 血清尿酸值を補正した後 }\end{array}$ & $\begin{array}{c}\text { 既知のリスクファクターと } \\
\text { 全ての痛風因子を補正した後** }\end{array}$ \\
\hline \multirow[t]{3}{*}{ 血清尿酸值 } & 全痛風患者 & $1.130(1.048-1.230)$ & $1.137(1.039-1.243)$ & - & $1.120 \quad(1.020-1.229)$ \\
\hline & 男性痛風 & $1.130(1.038-1.230)$ & $1.126(1.023-1.240)$ & - & $1.106 \quad(1.001-1.223)$ \\
\hline & 女性痛風 & $1.000(0.945-1.482)$ & $1.216(0.954-1.549)$ & - & $1.222 \quad(0.943-1.582)$ \\
\hline \multirow[t]{3}{*}{ 罹病期間 (年) } & 全痛風患者 & $1.012(0.994-1.030)$ & $1.001(0.981-1.022)$ & $1.004(0.983-1.025)$ & $0.989 \quad(0.965-1.013)$ \\
\hline & 男性痛風 & $1.015(0.996-1.034)$ & $1.002(0.981-1.023)$ & $1.008(0.987-1.030)$ & $0.993 \quad(0.969-1.018)$ \\
\hline & 女性痛風 & $0.998(0.933-1.067)$ & $0.976(0.897-1.061)$ & $0.973(0.885-1.071)$ & $(0.801-1.019)$ \\
\hline \multirow[t]{3}{*}{ 痛風結節 } & 全痛風患者 & $1.387(1.016-1.894)$ & $1.075(0.748-1.545)$ & $1.068(0.743-1.535)$ & $0.830 \quad(0.553-1.246)$ \\
\hline & 男性痛風 & $1.408(1.016-1.952)$ & $1.017(0.692-1.496)$ & $1.022(0.696-1.503)$ & $(0.524-1.236)$ \\
\hline & 女性痛風 & $1.351(0.476-3.829)$ & $1.620(0.554-4.736)$ & $1.504(0.518-4.369)$ & $1.062 \quad(0.293-3.853)$ \\
\hline \multirow[t]{3}{*}{ 関節数 } & 全痛風患者 & $1.175(1.096-1.260)$ & $1.123(1.037-1.215)$ & $1.098(1.014-1.189)$ & $1.097 \quad(0.995-1.210)$ \\
\hline & 男性痛風 & $1.176(1.093-1.266)$ & $1.112(1.022-1.210)$ & $1.094(1.005-1.192)$ & $(0.987-1.217)$ \\
\hline & 女性痛風 & $1.153(0.927-1.434)$ & $1.181(0.943-1.479)$ & $1.123(0.902-1.399)$ & $1.104 \quad(0.837-1.456)$ \\
\hline \multirow[t]{3}{*}{ 発作回数*** } & 全痛風患者 & $1.299(1.119-1.506)$ & $1.253(1.062-1.477)$ & $1.182(1.015-1.377)$ & $1.177 \quad(0.977-1.418)$ \\
\hline & 男性痛風 & $1.251(1.070-1.461)$ & $1.189(0.999-1.416)$ & $1.154(0.979-1.360)$ & $1.114 \quad(0.914-1.357)$ \\
\hline & 女性痛風 & $1.780(1.075-2.947)$ & $1.771(1.064-2.948)$ & $1.367(0.905-2.063)$ & $1.805 \quad(1.024-3.183)$ \\
\hline
\end{tabular}

数值はオッズ比 ( $95 \%$ confidence interval).

各群の症例数は全痛風患者28,639名(補正後22,649名), 男性痛風患者24,709名(補正後19,883名), 女性痛風患者2,189名(補正後1,891名)である.

* 既知のリスクファクターは年令,性別,喫煙歴,飲酒習慣,利尿薬の使用歴,総コレステロール值,トリグリセライド值,高血圧,糖尿病,BMI值を含める.

** 既知のリスクファクターと他の痛風因子を全て補正する ${ }^{* \star *}$ 痛風発作の頻度は1年に1回, 2 5回,6回以上に分類した 
表450才以上および50才未満痛風患者における心筋梗塞の痛風関連因子

\begin{tabular}{l|l|c|c|c|c}
\hline & & 補正前 & $\begin{array}{c}\text { 既知のリスクファクターを } \\
\text { 補正した後 }\end{array}$ & $\begin{array}{c}\text { 既知のリスクファクターと } \\
\text { 血清尿酸值を補正した後 }\end{array}$ & $\begin{array}{c}\text { 既知のリスクファクターと } \\
\text { 全ての痛風因子を補正した後** }\end{array}$ \\
\hline 血清尿酸值 & 50才以上 & $1.153(1.053-1.262)$ & $1.118(1.011-1.237)$ & - & $1.102(0.991-1.226)$ \\
\hline & 50才未満 & $1.238(1.045-1.467)$ & $1.199(0.989-1.454)$ & - & $1.219(0.997-1.491)$ \\
\hline 罹病期間 (年) & 50才以上 & $1.002(0.983-1.022)$ & $1.006(0.985-1.028)$ & $1.007(0.985-1.029)$ & $1.001(0.977-1.025)$ \\
\hline & 50才未満 & $0.983(0.930-1.038)$ & $0.951(0.889-1.017)$ & $0.976(0.916-1.039)$ & $0.890(0.818-0.968)$ \\
\hline 痛風結節 & 50才以上 & $0.941(0.649-1.364)$ & $0.853(0.558-1.306)$ & $0.846(0.553-1.295)$ & $0.603(0.372-0.977)$ \\
\hline & 50才未満 & $2.750(1.553-4.872)$ & $2.097(1.055-4.168)$ & $2.020(1.014-4.023)$ & $2.494(1.159-5.366)$ \\
\hline 関節数 & 50才以上 & $1.090(1.005-1.182)$ & $1.109(1.014-1.214)$ & $1.095(1.001-1.199)$ & $1.085(0.971-1.212)$ \\
\hline & 50才未満 & $1.191(1.030-1.377)$ & $1.108(0.936-1.312)$ & $1.041(0.875-1.239)$ & $1.138(0.923-1.403)$ \\
\hline 発作回数*** & 50才以上 & $1.209(1.016-1.438)$ & $1.256(1.034-1.526)$ & $1.188(0.994-1.420)$ & $1.199(0.963-1.492)$ \\
\hline & 50才未満 & $1.189(0.898-1.574)$ & $1.145(0.838-1.564)$ & $1.076(0.800-1.446)$ & $1.084(0.756-1.556)$ \\
\hline
\end{tabular}

数值はオッズ比 (95\% confidence interval).

各群の症例数は 50 才以上 ( $\geqq 50$ 才) 痛風患者 14,111 名(補正後 11,274名), 50 才未満 (<50才) 痛風患者 12,785 名 (補正後 11,220 名) である.

* 既知のリスクファクターは年令,性別,喫煙歴,飲酒習慣,利尿薬の使用歴,総コレステロール值,トリグリセライド值,高血圧,糖尿病,BMI值を含める

** 既知のリスクファクターと他の痛風因子を全て補正する ***痛風発作の頻度は1年に1回, 2 5回,6回以上に区分した

$50 才 以 上$ 痛風群においては, 心筋梗塞の関連 因子は，既知のリスクファクターを補正すると， 血清尿酸值, 関節数, 発作回数が有意な相関を 示した（表 4)。しかし，他の痛風因子を補正す ると，血清尿酸值，関節数と発作回数の有意な 相関がなくなり，50才以上痛風群における血清 尿酸值は他の痛風因子と緊密な相関を示した。 50才未満痛風群においては，心筋梗塞の関連因 子は，既知のリスクファクターを補正すると， 痛風結節の有無だけが有意な相関を示したが, 血清尿酸值は有意な相関を示さなかった（表 4 ）.

\section{考案}

本研究は, 和平医院痛風データベースにおけ る巨大な患者数のデータに基づいて痛風の臨床 因子と心筋梗塞の関連性を多変量解析で検討し, 痛風発作の重症度および血清尿酸值が心筋梗塞 の独立した関連因子であることを明らかにした。 全痛風患者に対する心筋梗塞の関連因子は，高 血圧，糖尿病，高脂血症などの既知のリスクフ アクターを補正すると, 痛風の臨床因子自体も 心筋梗塞の独立した関連因子となる。痛風の臨 床因子のうちで心筋梗塞と関連があるのは，血 清尿酸值, 痛風発作の回数および発作のあった
関節数であるが，それらのうちで血清尿酸值が 心筋梗塞の最も強い関連因子であることが明ら かになった，従来の報告では，痛風の有無ある いは血清尿酸值のいずれかを取り上げてアウト カームが検討されているが, 本研究では初めて 痛風発作の重症度と血清尿酸值を合わせたアウ トカームが検討され，相関があることが示され た。このことは非常に有意義と考える.

従来の報告では，血清尿酸值が虚血性心疾患 の独立したリスクファクターかどうかについて の結論は一致していないが (表 1), 本研究では 様々なリスクファクターを補正した後に血清尿 酸值と心筋梗塞の独立した相関が認められた。 心筋梗塞に対する血清尿酸值のオッズ比は 1.130 であった。つまり血清尿酸值は7.0 mg/ dLから $1 \mathrm{mg} / \mathrm{dL}$ 上昇すると心筋梗塞のリスクは $13 \%$ に 増加することから, 血清尿酸值の上昇に伴い心 筋梗塞のリスクも著しく上昇することがわかる. 従来の正常人のデータに基づいた研究では, 血 清尿酸值の区分はほとんど $7 \mathrm{mg} / \mathrm{dL}$ 以下に設定 されているため（表 1 ），血清尿酸值と虚血性心 疾患の間の関連は検出されにくくなることが, 本研究の結果から示唆される. 本研究では, 高 尿酸血症が持続して尿酸塩の関節への沈着が進 
んだ痛風患者を対象として検討したことによっ て，血清尿酸值と心筋梗塞の相関が明確になっ たと考えられる。

血清尿酸值の上昇は虚血性心疾患のリスクの マーカーと考えられているが，尿酸塩が動脈硬 化の病態に対してどのような役割を演ずるかは まだ不明である，血管の平滑筋増殖が動脈硬化 の病態の一つであることはよく知られているが 17)，最近の報告によると，血管の平滑筋の表面に 有機ア二オンのトランスポーターが存在し18), 平 滑筋に輸送された尿酸塩が平滑筋増殖を引き起 こす ${ }^{19)}$. 一方, in vitro試験ではあるが, 尿酸塩結 晶が血小板によるセロトニンとADPの分泌を促 進していることが明らかにされている20,21)。セロ トニンとADPは，血小板のアグリゲーション反 応 $^{21)}$ と顆粒球一内皮細胞反応 ${ }^{22)}$ を促進する作用 を介して, 内皮細胞の損傷, さらには動脈硬化 を引き起こす可能性があることが示唆された。 尿酸塩結晶が血管に沈着するというエビデンス はまだないが，痛風発作のあった関節数および 回数が血清尿酸值を補正しても心筋梗塞と有意 の相関があったという今回の結果からみると， 関節への尿酸塩結晶の沈着の程度がひどいほど 心筋梗塞の合併率も高くなる. 尿酸結晶沈着そ のものか，あるいは沈着の促進因子が心筋虚血 を惹起する可能性があると考えられるが，尿酸 塩結晶の心血管系への病原性についてはさらに 研究されるべき課題である.

関節への尿酸塩沈着は, 低温, 年令, 外傷, $\mathrm{pH}$ 值，プロテオグリカンなどによって促進され るが23)，尿酸塩が動脈硬化へ直接影響を与えてい るかどうかは未だ検討されたことがない．年令 が動脈硬化のリスクファクターであることは良 く知られているが17, 本研究においては尿酸塩沈 着が動脈硬化に与える影響も年令によって異な ることが示唆された. 50才未満痛風群の痛風患 者においては, 血清尿酸值や痛風発作の程度は 心筋梗塞とは関連がない。痛風結節のように尿 酸結晶沈着がかなりの重度まで進まないと心筋 梗塞のリスクは上昇しない. 50 才以上痛風群に 抢いては，血清尿酸值と痛風発作はいずれも心
筋梗塞の関連因子である，という結果からみる と, 尿酸沈着と関連のある動脈硬化は高齢群の ほうにリスクが高く，50才未满痛風群ではリス クはかなり低いことが示唆される。この結果か ら見ると, 若年医者を対象としたMeharryHopkins研究 ${ }^{13\rangle}$ では, 痛風の有無は虚血性心疾患 のリスクファクターとは認められなかった理由 も理解できる。

性別の違いによっても尿酸沈着が動脈硬化へ 与える影響が異なる。血清尿酸值や痛風発作の 程度は, 男性痛風群では心筋梗塞と関連がある が，女性痛風群ではいずれの痛風因子も心筋梗 塞と関連がないという結果が得られたが, これ は1988年のFramingham studyの結果 ${ }^{10)}$ と類似して いる。閉経は虚血性心疾患のリスクファクター の一つであるが(7), 女性痛風はほとんどの場合閉 経後に発症する ${ }^{24,25)}$ ので, 尿酸塩沈着の関与は 少ない。著者は, 女性は男性より虚血性心疾患 が発生しにくい理由について, 尿酸塩沈着によ る動脈硬化のリスクが男性より低いことに起因 すると考えているが，さらに種々の角度からの 研究を要する問題である.

本研究はprospectiveではなく retrospectiveな研究 であるため, 痛風と心筋梗塞のどちらが先行す るかは不明であって, 痛風が心筋梗塞のリスク ファクターであるとは即断できない. 研究の目 的のみで，多数の痛風患者を治療せずに数年間 も追跡することは倫理上でも問題があるし ${ }^{26)}$, 追 跡中の血清尿酸值や他のリスクファクターは生 活習慣の是正に伴い変動することもあるため, prospectiveな研究解析にも様々なバイアスが存在 する。現時点で痛風と虚血性心疾患の関連性を 解明するためには, 多数の retrospectiveな研究の 方が実施しやすい。今回の血清尿酸值だけでな く痛風発作の程度も心筋梗塞と関連があるとい う結果は，このretrospectiveな研究の欠点を十分 補償するものと考えている.

\section{結 論}

痛風は心筋梗塞と関連があるが，その関連性 は血清尿酸值だけではなく, 痛風発作の程度の 
関与も大きい. 尿酸塩沈着が心筋梗塞に与える 影響は年令および性別により異なる。

\section{文献}

1 ) Wortmann RL, Kelley WN: Gout and hyperuricemia. In: Ruddy S, Harris ED Jr, Sledge CB (eds) . Kelley' s Textbook of Rheumatology, 6th Ed, Philadelphia: WB Saunders, pp 1339-76, 2001.

2 ) Johnson MW, Mitch WE: The risks of asymptomatic hyperuricemia and the use of uricosuric diuretics. Drugs 21:220, 1981.

3 ) Tweddale MG, Fodor JG: Elevated serum uric acid: A cardiovascular risk factor. Nephron 23:3, 1979.

4 ) Fessel WJ: High uric acid as an indicator of cardiovascular disease, independence from obesity. Am J Med 68:401, 1980.

5 ) Freedman DS, Williamson DF, Gunter EW et al: Relation of serum uric acid to mortality and ischemic heart disease: the NHANES I epidemiologic follow-up study. Am J Epidemiol 141:637-644, 1995.

6) Wang J-G, Staessen JA, Fagard RH et al: Prognostic significance of serum creatinine and uric acid in older Chinese patients with isolated systolic hypertension. Hypertension 37:10691074, 2001.

7 ) Fang J, Alderman MH: Serum uric acid and cardiovascular mortality: the NHANES I epidemiologic follow-up study, 1971-1992. JAMA 283:2404-2410, 2000.

8 ) Alderman $\mathrm{MH}$, Cohen $\mathrm{H}$, Madhavan $\mathrm{S}$ et al: Serum uric acid and cardiovascular events in successfully treated hypertensive patients. Hypertension 34:144-150, 1999.

9 ) Verdecchia P, Schillaci G, Reboldi G et al: Relation between serum uric acid and risk of cardiovascular disease in essential hypertension: The PIUMA study. Hypertension 36:1072-1078, 2000.

10) Abbott RD, Brand FN, Kannel WB et al: Gout and coronary heart disease: the Framingham study. J Clin Epidemiol 41 （3）: 237-242, 1988.
11) Freedman DS, Williamson DF, Gunter EW et al: Relation of serum uric acid to mortality and ischemic heart disease: the NHANES I epidemiologic follow-up study. Am J Epidemiol 141:637-644, 1995.

12) Culleton BF, Larson MG, Kannel WB et al: Serum uric acid and risk for cardiovascular disease and death: the Framingham heart study. Ann Intern Med 131:7-13, 1999.

13) Gelber AC, Klag MJ, Mead LA et al: Gout and risk for subsequent coronary heart disease: the Meharry-Hopkins study. Arch Intern Med 157:1436-1440, 1997.

14) Alderman $\mathrm{MH}$, Cohen $\mathrm{H}$, Madhavan $\mathrm{S}$ et al: Serum uric acid and cardiovascular events in successfully treated hypertensive patients. Hypertension 34:144-150, 1999.

15) Verdecchia P, Schillaci G, Reboldi G et al: Relation between serum uric acid and risk of cardiovascular disease in essential hypertension: The PIUMA study. Hypertension 36:1072-1078, 2000.

16) Goldschlager N, Goldman MJ: Electrocardiography: Essentials of interpretation. LANGE Medical Publications, pp 85-120, 1984.

17) Ridker PM, Genest J, Libby P: Risk factors for atherosclerotic disease. In: Braunwald E, Zipes DP, Libby P (eds) . Heart disease: A textbook of cardiovascular medicine, 6th ed. Philadelphia: WB Saunders, pp 1010-1039, 2001.

18) Kanellis J, Watanabe S, Li JH et al: The evidence for a functional organic anion transporter in vascular smooth muscle cells. Presented at: American Society of Nephrology 35th Annual Meeting and Scientific Exposition. October 30November 4, 2002; Philadelphia, Pa. In: Program and Abstracts, 13:329A.

19) Johnson RJ, Kang D-H, Feig D et al: Is there a pathogenetic role for uric acid in hypertension and cardiovascular and renal disease? Hypertension 41:1183-1190, 2003.

20) Ginsberg MH, Kozin F, O' Malley $M$ et al: 
Release of platelet constituents by monosodium urate crystals. J Clin Invest 60:999-1007, 1977.

21) Ginsberg $M$, Henson $P$, Henson $J$ et al: Mechanisms of platelet response to monosodium urate crystals. Am J Pathol 94 (3) :549-568, 1979.

22) Boogaerts MA, Hammerschmidt ED, Roelant $C$ et al: Mechanisms of vascular damage in gout and oxalosis: crystal induced, granulocyte mediated, endothelial injury. Thromb Haemost 50 (2) :576-580, 1983.

23) Palella TD, Fox IH: Hyperuricemia and gout. In: Scriver CR, Beaudet AL, Sly WS, Valle D (eds). The metabolic basis of inherited disease, 6th ed. New York: McGraw-Hill, pp 965, 1989.

24) Lally EV, Ho G Jr, Kaplan SR: The clinical spectrum of gouty arthritis in women. Arch Intern Med 146: 2221-2225, 1986.

25) Puig JG, Michan AD, Jimenez ML et al: Female gout: Clinical spectrum and uric acid metabolism. Arch Intern Med 151: 726-732, 1991.

26) Crombie IK, Davies HTO: Cohort studies. In: Research in health care. New York: John Wiley \& Sons, pp 107-122, 1996. 


\title{
The association between myocardial infarction and the severity of gouty arthritis in Taiwan
}

\author{
Shih-Yang Chen ${ }^{1)} \quad$ Naoyuki Kamatani ${ }^{2)}$
}

To examine whether serum urate level and other aspects of gouty arthritis are independently associated with myocardial infarction (MI) in the gouty population, we performed a retrospective study. A total of 22,572 gouty cases were enrolled. MI was defined as a positive finding by the resting electrocardiographic criteria. The variables of gout were tested univariately and multivariately, respectively, controlling for the covariates by logistic regression analysis. The above analysis was then repeated in subgroups of youngaged $(<50$ years $)$, old-aged ( $\geq 50$ years $)$, male, and female patients. The results were that serum urate level was significantly associated with MI in all subjects and male subgroup. After controlling for serum urate level and the covariates, increased affected joint count was also independently associated with MI in the all subjects, male and old-aged subgroups. Tophi formation was independently associated with MI in young-aged subgroup. None of the variables of gout was significantly associated with MI in the female subgroup after controlling for serum urate level and covariates. The conclusions of this study were that it first demonstrates that gout is associated with MI by both hyperuricemia and the severity of gouty arthritis independently, while the association of urate to MI could be different between age strata and genders.

1) Section of Gout, Department of Internal Medicine, Taipei Municipal Hoping Hospital, Taiwan

2 ) Institute of Rheumatology, Tokyo Women's Medical University, Japan. 